\title{
THE CLIMATE OF SOUTHERN CALIFORNIA.
}

Messrs. Editors, - Since my arrival here, extending over a period of six months, one thing has particularly impressed me, namely, how little is known in Boston regarding California. I knew from what I had read on the subject that Santa Barbara was a good place for invalids; probably it is the one best known in Boston; it certainly is the one most visited and best liked by Boston people. Its position on the map will show how well protected it is. The town has a southern exposure; towards the ocean high islands afford protection from the winds; behind, the mountains of the Coast Range rise very close to the town, keeping off cold north winds which would otherwise be very disagreeable. It therefore has very great advantages of location, and attracts by its really fine climate. To one leaving Boston late in the fall or early in winter and going directly to Santa Barbara the change is delightful. Instead of cold November rains and a dreary landscape he can enjoy an almost uninterrupted succession of sunny days, open windows, and out-door life. From my short experience there and conversation with others who have had more of a trial of Californian climate, I concluded that a very great improvement could be made on Santa Barbara by going a little farther inland. The air of Santa Barbara is delicious, but in the middle of the forenoon, when the sun reaches the zenith, the light breeze heavily laden with moisture blows up fresh and cool from the ocean, making the atmosphere very bracing, and this is just the trouble with it. Any one with disease affecting the respiratory organs, especially if it is advanced sufficiently to demapd a change, cannot endure so much stimulating sea-air. In the latter winter and the spring months there is also much fog and dampness, particularly at night. In other words, Santa Barbara is a sea-coast town, and some of the disadvantages inseparable from coast towns affect her residents. But these objections can be overcome by going inland a few miles, among the foot-hills. Here an invalid finds all the advantages that Sauta Barbara offers (excepting that he has less society, and perhaps Santa Barbara has too much dancing and gayety at its large hotels), and in addition a dry air, finer scenery, more game, etc. The Ojai is just such a spot, and one of the most desirable. It is an Indian name, meaning a crescent, adopted and spelled by the Mexicans, who applied it to a large grant held from their government, and nearly covering the whole valley, which was afterwards called the Ojai Valley. About six years ago the land covered by the Ojai grant under a patent from the United States passed into the hands of some gentlemen connected with the Pennsylvania railroad. They sold the land, which has now been cut up into small ranches. It lies among the foothills of the Coast Range, ten miles from the 'Pacific and one thousand feet above the sea. San Buenaventura is fifteen miles distant. To Santa Barbara through a fine mountain pass it is thirty miles. San Buenaventura is the business centre, and here several times a week the steamers of the coast-line call on their way to and from San Francisco. To San Francisco it is four hundred miles. To Newhall, the nearest station on the railroad, is fifty miles. To Los Angeles, seventy-five miles. The Ojai Valley is eight or ten miles long 
east and west, and from a width of three miles at the west end it tapers to about a mile at the east. To the north of the valley the mountains rise very abruptly to a height of four thousand feet above the valley and five thousand feet above the sea. On the south they are much smaller, running off in some places to high hills. To the east the ranges on the north and south approach each other, and the end is filled up by a fine mountain, Santa Paula. The sides of these ranges are furrowed and broken by deep cañons which run far up their sides. They are covered with live-oaks, sage brush, and chaparral. The surface of the valley is very even for so hilly a neighborhood, and is dotted all over with clumps of evergreen oaks. These live-oaks of California are beautiful trees, scattered about, having large trunks and branches, often twisted and gnarled, with fine tops of bright, clean, evergreen leaves, white oaks and sycamores being intermixed. In places where the land is rolling and the trees collect in clumps, an appearance like an English park is presented. In the middle of the valley a town site was laid out three years ago, and named Nordhoff. Here have been built a post-office, grocery store, hotel, school-house, church, and private houses. A mile up the valley is a private boarding-house. All up and down the valley are the houses of farmers. At a distance of seven miles up a cañon are the Matilche hot sulphur springs, where cottages, bath-houses, and a hotel have been built. There are also two or three other warm sulphur springs in the valley. The temperature of the air here is not quite so even, taking an average of the whole year, as on the coast. It is slightly colder in winter and warmer in summer. There is considerable change every day, the nights being quite cool, while during the day it often gets very warm, even in the winter months; there have never been any reliable observations made here. Ice and snow are so rare that they may be said never to be seen. In winter after sunset and in the early morning till eight o'clock, perhaps, a fire is needed; all the sitting rooms are provided with open fire-places, and during the evening a fire is comfortable and cheerful. In the middle of the day, in January and February, the thermometer often reaches $80^{\circ} \mathrm{F}$. in the shade, and in the summer it will reach $100^{\circ} \mathrm{F}$. on the hottest days. But the heat is never oppressive. The air is always dry and invigorating, and does not cause any exhaustion when at its hottest, as it does at lower temperatures in the Atlantic States. In the summer the tradewinds always begin to blow here by the middle of the forenoon, and even in the hot weather one is seldom desirous of stopping long in the shade; so, to give you figures of the thermometer, conveys a poor idea of the effects of temperature on the body. Taken the year through the temperature is very even. The changes are regular and constant, and can be provided for. The days are always comfortable for riding or working in the open air, and the nights are always cool enough for refreshing sleep. It is the country for out-door life: in the winter it is always cooler in the house than out-doors; in the summer it is cooler out-doors than in the house. One can sit during any day of the year, with few exceptions, in the house, with doors and windows thrown wide open, and be comfortable. Or he can throw off his coat and go out in the sun, and walk, ride, or work without exhaustion. Sunstroke is said to be unknown here. Straw hats are in season every month of the year. The people who 
live here tell me they wear the same weight and material in clothing the year round. The air is much drier here than in Santa Barbara or other places on the coast. On going out in the evening I am often impressed with the dryness of the air as it strikes my face. In the spring there are some dews at night. Occasionally in the spring months, during the night, a slight fog will roll up into the valley, but it is only when there is an unusually heavy fog on the coast; generally when they are having heavy fogs every night on the coast only an occasional and comparatively light one is seen here. From January till April is the rainy season so called, but during that time we have had only five rains that would amount to as many good showers almost any July in Massachusetts. Still the fields and hill-sides are green, and foliage everywhere is as bright and fresh as in New England in June. There are no diseases here which the stranger need dread any more than at home. There are no malarial affections in this locality. The usual diseases which prevail among people in New England are met with here. There is plenty to amuse and interest a sportsman. Game, both large and small, is very abundant, and the fishing is excellent.

Vegetation is luxuriant and varied. The ferns in particular are to be noticed, several rare species being found here. In this country everybody rides; a very good horse, with saddle and bridle, can be bought for forty dollars. A large proportion of the people are of Spanish descent, and the style of riding and equipment is entirely Spanish. As soon as a man gets here with his family he has to buy a horse for his children. All the small boys of Santa Barbara spend most of their time horse-racing about the streets; they ride bareback on the full run while they are so small that their legs stand out at right angles from their bodies. Every morning I see three little girls ride to school, sitting one behind the other, with their books under their arms, looking about over the landscape with serious, unconcerned faces, as though they had no idea they were doing anything strange. There is plenty to in terest visitors stopping here: one meets with very pleasant people; the hotel and boarding house have had a number of guests all winter who have been riding, hunting, and exploring the country ; they have gotten up picnics, entertainments in the school-house, played croquet, etc., passing the time pleasantly enough. All have expressed themselves as pleased with the country and as improved in health, and without exception give this place the preference to Santa Barbara. There has been a Chicago physician here who has traveled extensively for his wife's health; he says he has found nowhere a climate which seems to him so well fitted to benefit lung diseases; he prefers it to the health resorts on the Mediterranean. Another gentleman, who spent last winter at Mentone, says this climate is much freer from dampness and cold winds. He improved here much more than while there. A young man who has spent several winters at the South considers this climate better than that of Florida or of the. West Indies. Of course these are isolated opinions, and show the result on individual cases. But I don't see why this climate is not excellent. It is not debilitating like that of the South; it is desirable and comfortable all the year round; and the winters are not so cold as in Colorado or Minnesota. The fact that it is a climate which is good at all seasons, 
and not to be aroided half the year on account of excessive heat or some dreaded diseases, makes Southern California especially adapted to those cases where a long change of residence is contemplated. In this connection let mo say that the cost of living is very light. It is quite common for two young men who have come for ther̃r health, perhaps, to hire a little cottage and do their own cooking. Without any particular exertion in the way of economy their expenses may all be included inside two hundred dollars each a year. This sum will pay their rent, food, fuel, lights, washing, and horse feed. Some of those living in this way who are in poor circumstances do. light work occssionally on the ranche, which brings them in a little money and perhaps does them good besides. Any one to be permanently relieved by climate should take a protracted course of the medicine, and those who have come here and remained some time have been benefited if not cured. Those, wishing to spend any length of time here can pleasantly and profitably employ themselves in raising fruit. The soil is well adapted to growing all kinds of fruit. The dryness of the air, warmth of the sun, and sheltered location of the valley render it especially fitted for all kinds of dried fruit, as raisins, prunes, apricots, plums, peaches, etc., which bring a good return on money invested.

To sum up: the advantages which Southern California, and particularly the Ojai Valley, offer to invalids are (1) mildness of temperature, (2) equability of climate, (3) dryness of atmosphere, (4) sheltered situation, (5) freodom from malarious diseases, and (6) plenty to amuse and interest visitors. The only disadvantage that I know of is its distance from Boston.

Very truly yours, W. H. FRENCH, M. D.

Nordhoff, Ojai Valiet, Ventura Co., California.

COMPARATIVE MORTALITY-RAFES FOR THE WEEK ENDING SEPTEMBER 1, 1877.

\begin{tabular}{l|c|c|c|c}
\hline & $\begin{array}{c}\text { sistimated Population, } \\
\text { July 1, 1877. }\end{array}$ & $\begin{array}{c}\text { Total Mortality } \\
\text { for the Weok. }\end{array}$ & $\begin{array}{c}\text { Annual Desth-Rate } \\
\text { per 1000 for the Woek. }\end{array}$ & $\begin{array}{c}\text { Death-Rate for the } \\
\text { Year 1876. }\end{array}$ \\
\cline { 2 - 3 } New York & $1,077,228$ & 644 & 31.29 & 27.46 \\
Philadelphia & 850,856 & 330 & 20.17 & 22.88 \\
Brooklyn & 527,830 & 298 & 29.35 & 24.31 \\
Chicago & 420,000 & 191 & 23.65 & 20.41 \\
Boston & 363,940 & 184 & 26.29 & 23.39 \\
Providence & 103,000 & 53 & 26.75 & 18.34 \\
Worcester & 52,977 & 26 & 25.52 & 22.00 \\
Lowell & 53,678 & 25 & 24.22 & 22.21 \\
Cambridge & 51,572 & 23 & 23.19 & 20.54 \\
Fall River & 50,372 & 40 & 41.29 & 22.04 \\
Lawrence & 37,626 & 18 & 24.85 & 23.32 \\
Lynn & 34,524 & 14 & 21.08 & 21.37 \\
Springfield & 32,976 & 9 & 14.19 & 19.69 \\
Salem & 26,739 & 17 & 33.06 & 23.57 \\
\hline
\end{tabular}

